\title{
Laparoscopic cholecystectomy in 960 elderly patients
}

\section{Colecistectomia videolaparoscópica em 960 pacientes idosos}

\author{
Edson Ricardo loureiro, ACBC-ES 1; Suellen Christina Klein 2; Claudia Cleto Pavan 3; Lady Dina Lopes Freire Almeida 3 ; \\ Fernando Henrique Pereira da Silva ${ }^{3}$; Danilo Nagib Salomão Paulo, tCBC-ES 4
}

A $B$ S T $T$ R A C T

\begin{abstract}
Objective: to evaluate the operative time, hospital stay, conversion rate, morbidity and mortality in elderly patients undergoing laparoscopic cholecystectomy for gallbladder disease. Methods: we conducted a descriptive, retrospective Study with the chats of 960 patients of both genders, aged 60 and 97 years in the period from January 1993 to August 2009. Results: operative time ranged from nine to 180 minutes. The length of stay ranged from 24 to 120 hours. Conversion occurred in 28 patients $(2.92 \%)$, of which $67.9 \%$ were women and $28.6 \%$ men, a minilaparotomy having been performed in 11 cases (39.3\%) and in $17(60.7 \%)$ the conventional open route. The perioperative complications were two ruptures of the gallbladder, a failure in the pneumoperitoneum and in clipping of the cystic duct. Post-operative complications were five umbilical incisional hernias. Systemic complications were: nine arrhythmias, one postoperative jaundice, one acute myocardial infarction and one mesenteric infarction. Mortality occurred in three patients $(0.3 \%)$, one due to perioperative myocardial infarction, one due to sepsis and one because of the mesenteric infarction. Conclusion: elderly patients undergoing laparoscopic cholecystectomy had low hospital stay and low morbimortality. The operative time and hospital stay were short, demonstrating that laparoscopic cholecystectomy is safe and effective in the elderly.
\end{abstract}

Key words: Cholescystectomy. Cholecystectomy, laparoscopic. Gallbladder diseases. Aged.

\section{INTRODUCTION}

C holecystolithiasis occurs among 3 to $20 \%$ of the world population'. It is the most common abdominal surgical disease in the elderly, with prevalence of $21.4 \%$ for the aged 60 to 69 years and $27.5 \%$ in individuals aged over 70 years ${ }^{2}$. The symptoms are absent between $50 \%$ and $77 \%$ of cases ${ }^{3,4}$, but presentments of worsening and complicated biliary calculi are frequent.

Laparoscopic cholecystectomy (LPC) is considered the gold standard treatment for this disorder. Cholecystectomy is the most frequent abdominal operation and its employment in the elderly varies between $8.3 \%$ and $\% 24 \%^{2}$. It was estimated in 2007 that $90 \%$ of cholecystectomies in Brazil would be performed by the laparoscopic access, a percentage reached by the USA in the year $1992^{5}$.

Although aging seems to have a negative influence on surgical outcome, most publications show that the chronological age alone is irrelevant. In reality, the decline of functional reserves, the more frequent presence of comorbidities, chronic and complicated biliary disease, such as acute cholecystitis and biliary pancreatitis commonly associated with calculi of the common bile duct - are the greatest responsible for causing potential increase in perioperative morbidity, in mortality and in need for conversion to open technique. Therefore, elective surgical treatment is recommended for the clinically symptomatic elderly, as long as they are compensated ${ }^{2}$.

This study aims to analyze the operative time, hospital stay, conversion rate, morbidity and mortality in the elderly undergoing LPC.

\section{METHODS}

This research was approved by the Committee of ethics in research in humans of the Superior School of Sciences, Vitória Santa Casa de Misericórdia, under number 022-2007. It is descriptive, retrospective, upholding 960 elderly patients, aged between 60 and 97 years old ( $\mathrm{AV}=$ $70.01 \pm 7.67$ years). There was higher prevalence of

Work conducted in the Discipline of Fundamentals of Surgery of the Superior School of Sciences, Santa Casa de Misericórdia de Vitória, Espírito Santo - ES, Brazil.

1. Assistant Professor, Fundamentals of Surgery, Superior School of Sciences, Santa Casa de Misericórdia de Vitória, Espírito Santo - ES, Brazil; 2. Staff Physician, Santa Casa de Misericórdia de Vitória, Espírito Santo - ES, Brazil; 3. Medical School Graduate, Surgery, Superior School of Sciences, Santa Casa de Misericórdia de Vitória, Espírito Santo - ES, Brazil; 4. Professor, Department of Surgery, Superior School of Sciences, Santa Casa de Misericórdia de Vitória, Espírito Santo - ES, Brazil. 
individuals in the seventh decade of life. Of the patients, 679 were female (70.73) and 281 males (29.27\%).

Gallbladder disease was confirmed through anamnesis, physical examination, laboratory and ultrasound. The definitive diagnosis was given by macro and microscopic examination of the gallbladder.

Laparoscopic cholecystectomies were conducted by the same surgeon (ERL) in the period from January 1993 to August 2009.

The information was taken from patient registration cards. The data required were manipulated through Microsoft Excel program, and subsequently analyzed according to conversion rate, operative time, hospital stay, surgical morbidity and mortality.

Chronic cholecystitis was the most frequent surgical indication $(86.67 \%)$, followed by acute cholecystitis (10.63\%) and gallbbladder polyp (1.04\%) (Table 1).

There were 37 patients $(3.85 \%)$ with cholelithiasis-associated biliary diseases. Of these, 30 (3.13\%) had choledocholithiasis and seven $(0.73 \%)$ neoplasm of the gallbladder. In the latter group, two cases were identified during surgery, necessitating conversion to laparotomy and operation specific to the disease. The other five were diagnosed by Histopathological examination of the gallbladder, of which three needed reapproach by laparotomy and specific operation due to the advanced stage of disease, and two did not need a new procedure, as the tumor was restricted to the mucosa.

The choledocholithiasis was treated with preoperative Endoscopic Retrograde Cholangiopancreatography $E R C P$, withdrawal of calculi through the cystic duct in the cases of small calculi and wide cystic duct, or through the main bile duct when the calculi were bigger. In those with bile duct diameter greater than 1.5 and with multiple calculi, we performed a choledoco-duodenal anastomosis.

In 16 patients (1.67\%) concomitant procedures to the LPC were carried out in the biliary tree: nine choledoco-duodenal anastomoses, six choledocotomies with choledocostomy and one choledocoscopy.

Extrabiliary diseases have also been detected in 115 individuals (11.98\%), with predominance of hiatal hernia (4.9\%), umbilical hernia (1.67 percent) and inguinal hernia (1.25\%) (Table 2).

In 104 patients (10.83) we conducted extrabiliary concomitant procedures: 47 hiatal hernioplasties (4.9\%); 21 (2.19\%) umbilical hernioplasties, of which five were for correction of incisional umbilical hernia; 13 (1.35\%) liver biopsies; 12 (1.25\%) inguinal hernioplasties; two

Table 1 - Gallbladder Diseases found preoperatively.

\begin{tabular}{|c|c|c|}
\hline Gallbladder diseases & Absolute frequency & Relative frequency (\%) \\
\hline Chronic cholecystitis & 832 & 86.67 \\
\hline Acute cholecystitis & 102 & 10.63 \\
\hline Gallbladder polyp & 10 & 1.04 \\
\hline Acutized chronic cholecystitis & 3 & 0.31 \\
\hline Chronic cholecystitis and biliary polyp & 1 & 0.10 \\
\hline Undefined & 12 & 1.25 \\
\hline Total & 960 & 100.00 \\
\hline
\end{tabular}

Table 2 - Extrabiliary Diseases associated with cholelithiasis.

\begin{tabular}{|c|c|c|}
\hline Extrabiliary diseases associated to cholelithiasis & Absolute frequency & Relative frequency (\%) \\
\hline Hiatal hernia & 47 & 4.90 \\
\hline Umbilical hernia & 16 & 1.67 \\
\hline Inguinal hernia & 12 & 1.25 \\
\hline Liver cirrhosis & 11 & 1.15 \\
\hline Incisional umbilical hernia & 5 & 0.52 \\
\hline Peritoneal Carcinoma & 3 & 0.31 \\
\hline Ascites & 2 & 0.21 \\
\hline Hepatic cyst & 2 & 0.21 \\
\hline Lumbar hernia & 2 & 0.21 \\
\hline Neoplasm of colon & 2 & 0.21 \\
\hline Other* & 13 & 1.35 \\
\hline Total & 115 & 11.98 \\
\hline
\end{tabular}

* Liver Abscess, appendicitis, atoxic goiter, ovarian cyst, ureteral stenosis, femoral hernia, Ichthyosis, lipoma of the intestinal wall, bladder stones, megaesophagus, pancreatic neoplasia, sigmoid colon neoplasia and situs inversus totalis. 
colectomies $(0.21 \%)$; two resections of hepatic cyst $(0.21 \%)$; two lumbar hernioplasties $(0.21 \%)$, In addition to appendectomy $(0.001 \%)$, hepatic abscess drainage $(0.001 \%)$, ovarian cyst excision $(0.001 \%)$, femoral hernioplasty and prostate transurethral resection $(0.001 \%)$.

Descriptive statistics was used for calculating the arithmetic mean and standard deviation of nominal variables. The percentage and absolute frequency were used as categorical variables.

\section{RESULTS}

Operative time varied between nine and 180 minutes ( $A V=44.22$ minutes; $S D=27.94)$. The hospital stay ranged from 24 to 120 hours ( $A V=25.38$ hours; $S D=$ 7.15). Only one woman, 88 years, operated in 1996 was hospitalized for 120 hours.

Twenty-eight patients $(2.92 \%)$ required conversion to laparotomy, eight being in octogenarian (28.6\%). Of these, $67.9 \%$ were females and $28.6 \%$ males. In 11 cases (39.3\%) a minilaparotomy was held and in $17(60.7 \%)$ the conventional open route. The conversion resulted in an average time of hospitalization of 36.9 hours and operative time average of 67.6 minutes, values greater than the general sample. The most prevalent disease of biliary surgery in these cases was chronic cholecystitis $(82.1 \%)$. The factors that influenced the increase in the rate of conversion were: little experience of the surgeon, with little training in the early years of introduction of the laparoscopic method, equipment problems, choledocholithiasis identified perioperatively, calculi impacted in the papilla, multiple adhesions, severe acute cholecystitis and sessile scleroatrophic gallbladder. seen in table 3.

\section{DISCUSSION}

The LPC is the gold standard for treatment of cholelithiasis in elderly patients ${ }^{6}$. It is an operation that was widespread in Brazil and in the world in recent decades. The number of interventions over the period studied enabled evaluation of surgical outcomes since the beginning of its employment in the State of Espírito Santo, in 1993.

The age of patients is a factor that has worried surgeons. However, this variable alone is not able to preclude laparoscopy ${ }^{7}$. The most relevant aspect is the presence of comorbidities with age progression.

In this work, the average surgical time of 44.22 minutes can be considered low compared to most recent publications ${ }^{8-10}$. This value tends to decrease with surgeon experience, surgical team joint working time and with the systematization of the technique. Reducing operative time is interesting for the elderly patient because it decreases surgical trauma and anesthetic drug use. One should be advised, however, to avoid hasty maneuvers due to increased risk of iatrogenic lesions. On the other hand, the delay in conclusion of LPC can be a risk factor for postoperative complications ${ }^{11}$. The important thing is that the operation be performed safely, effectively and in a timely manner.

The average hospital stay of 25.38 hours was also low. Other works described average 2.9 days $^{12}$, three days ${ }^{9}$ and 3.99 days $^{13}$. There are reports of "day-care" hospitalization (4 to 6 hours) ${ }^{14}$. This short period of hospitalization is recommended for young people and should be viewed with great reserve for the elderly. We must remember that only a patient out of the 960 operated was hospitalized for 120 hours, causing the average hospital stay to increase. She featured associated comorbidities not recorded in her registration form. She was submitted to intraoperative cholangiography and choledoco-duodenal anastomosis, evolving without complications

Table 3 - Perioperative and postoperative complications arising from LPC performed on 960 elderly in the period from January 1993 to August 2009.

\begin{tabular}{|c|c|c|c|}
\hline Peri and postoperative & surgical complications & Absolute Frequency & Relative Frequency (\%) \\
\hline \multirow{5}{*}{ Perioperative } & Cardiovascular events (arrhythmias) & 9 & 0.94 \\
\hline & Rupture of gallbladder & 2 & 0.21 \\
\hline & Failure in pneumoperitoneum & 1 & 0.10 \\
\hline & Failed to clip the cystic duct & 1 & 0.10 \\
\hline & Death by $\mathrm{AMI}^{+}$ & 1 & 0.10 \\
\hline \multirow[t]{3}{*}{ Postoperative } & Post-LPC incisional umbilical hernia & 5 & 0.52 \\
\hline & Death* & 2 & 0.21 \\
\hline & Jaundice & 1 & 0.10 \\
\hline \multirow[t]{3}{*}{ Total morbimortality } & & 22 & 2.29 \\
\hline & Total morbidity & 19 & 1.98 \\
\hline & Total mortality & 3 & 0.31 \\
\hline
\end{tabular}

* Postoperative deaths were caused by sepsis (1), mesenteric infarction (1) and AMl+ (acute myocardial infarction - 1). 
The conversion rate of $2.92 \%$ observed in this work is very close to the lower limit of the variation of $2 \%$ to $26.5 \%$ found in other reports ${ }^{5,15}$. This rate was $28.6 \%$ in octogenarians, possibly due to prolonged biliary disease time. This time causes higher probability of migrating gallstones, crises outbreaks, intra-abdominal adhesion formation and anatomical changes, situations which hamper laparoscopy. Patients who need conversion tend to display longer operative time ${ }^{5}$, and this was repeated in this study, but mortality was not elevated. The conversion was more frequent in women subjected to LPC for treating chronic cholecystitis. However, we cannot say that there is no significant relationship between these data (women and chronic cholecystitis) and indication of conversion, because $70.73 \%$ of the sample was composed of women, and $86.67 \%$ of all individuals were bearers of chronic cholecystitis.

During the learning curve, a more experienced surgeon is important, since the lack of training is one of the key factors for conversion. We note that conversion is related to the following situations: technical difficulty to dissect the structures of the biliary pedicle, acute cholecystitis, bleeding, iatrogenic injury to the bile duct ${ }^{16,17}$, choledocholithiasis, scleroatrophic gallbladder ${ }^{5}$ and male gender with acute cholecystitis ${ }^{15}$. The difficulty of identification of anatomical structures has also been emphasized as a cause of conversion ${ }^{18}$. In this study, the causes of conversion were: little experience of the surgeon, with little training in the early years of the laparoscopic method; defect in equipment; choledocholithiasis perioperatively identified; calculi impacted in the papilla; multiple adhesions; severe acute cholecystitis; and sessile scleroatrophic gallbladder.

Morbidity was $1.98 \%$ and, when summed to mortality $(0.31 \%)$, the frequency of complications was $2.3 \%$. This morbidity was lower than that reported by several authors ${ }^{12,19-21}$. The vast majority of perioperative and postoperative complications had little or no impact on the final results. The arrhythmias were quickly reversible; the jaundice by indirect hyperbilirubinemia regressed quickly and spontaneously; failures in pneumoperitoneum and clipping of the cystic duct were promptly corrected. The incisional umbilical hernias that emerged postoperatively were also corrected.

The LPC is a safe procedure and consecrated in seniors, but in patients with complicated biliary disease it can be associated with increased postoperative morbidity ${ }^{22}$. Morbidity after LPC was more associated with biliary disease severity than with chronological age. In octogenarians, LPC should be held early, in non-complicated stages, to improve perioperative outcomes ${ }^{8}$.

When there is great difficulty in identifying the anatomy of the bile duct in LPC, using a $30^{\circ}$ laparoscope, dissection next to the infundibulo-cystic junction, partial resection of gallbladder and the conversion to open procedure can avoid injury to important structures. It is still noteworthy that morbidity can be linked to operative time period exceeding two hours, acute cholecystitis, diabetes mellitus ${ }^{11}$ and ASA e" 3 patients ${ }^{23}$. The neuroendocrine and inflammatory responses lower than that of conventional cholecystectomy may also contribute to the lower morbidity of laparoscopic cholecystectomy ${ }^{24}$.

Mortality of LPC was relatively low: $0.31 \%$. Some authors have described death rates ranging between $0 \%$ and $2 \% .{ }^{9}, 15,19,25,26$ In this work, the causes were represented by three major conditions: sepsis, mesenteric infarction and myocardial infarction. The latter was also observed by Brunt et $a . .^{21}$ and more recently by Malik et al. ${ }^{10}$. Other causes of death have been described ${ }^{25}$. This result confirms the fact that systemic complications predominate as higher risk factors, requiring thorough appreciation of the surgical risk classification in people with multiple comorbidities from medical professionals, mainly in elderly patients. Thus, taking preoperative preventive measures is of the utmost importance.

In conclusion, elder patients undergoing laparoscopic cholecystectomy had low hospital stay and low morbimortality. The operative time and hospital stay were short, demonstrating that laparoscopic cholecystectomy is a safe and effective procedure in the elderly.

\title{
R E S U M O
}

\begin{abstract}
Objetivo: Analisar o tempo operatório, a permanência hospitalar, a taxa de conversão, a morbidade e a mortalidade de pacientes idosos submetidos à colecistectomia videolaparoscópica por doença da vesícula biliar. Métodos: Estudo descritivo, retrospectivo, realizado no prontuário de 960 pacientes, de ambos os sexos, com idade entre 60 e 97 anos no período de janeiro de 1993 a agosto de 2009. Resultados: O tempo operatório variou de nove a 180 minutos. O tempo de internação variou de 24 a 120 horas. A conversão ocorreu em 28 pacientes (2,92\%), dos quais 67,9\% eram mulheres e 28,6\% homens tendo sido em 11 casos (39,3\%) realizada minilaparotomia e em $17(60,7 \%)$ a via aberta convencional. As intercorrências no transoperatório foram duas rupturas da vesícula biliar, uma falha no pneumoperitônio e uma na clipagem do ducto cístico. No pós-operatório observaram-se cinco hérnias umbilicais incisionais. As complicações sistêmicas foram: nove arritmias cardíacas, uma icterícia pós-operatória, um infarto agudo do miocárdio e um infarto enteromesentérico. Mortalidade ocorreu em três pacientes $(0,3 \%)$, um por infarto agudo do miocárdio no transoperatório, uma sepse e um infarto enteromesentérico. Conclusão: Os pacientes idosos submetidos à colecistectomia videolaparoscópica apresentaram baixo tempo de internação hospitalar e baixa morbimortalidade. O tempo operatório e o de internação hospitalar foram curtos, demonstrando que a colecistectomia videolaparoscópica é procedimento seguro e eficaz nos idosos.
\end{abstract}

Descritores: Colecistectomia. Colecistectomia laparoscópica. Doenças da vesícula biliar. Idoso. 


\section{REFERENCES}

1. Tang B, Cushieri A. Conversion during laparoscopic cholecystectomy: risk factors and effects on patient outcome. J Gastrointes Surg 2006; 10(7):1081-91.

2. Régo RE, de Campos T, de Moricz A, Silva RA, Pacheco Júnior AM Cholecystectomy in the elderly: early results of open versus Iparoscopic approach. Rev Assoc Med Bras 2003; 49(3):293-9.

3. Picci R, Perri SG, Dalla Torre A, Pietrasanta D, Castaldo P, Nicita A et al. Therapy of asymptomatic gallstones: indications and limits. Chir Ital 2005; 57(1):35-45.

4. Sakorafas GH, Milingos D, Peros G. Asymptomatic cholelithiasis: is cholecystectomy really needed ? A critical reappraisal 15 years after the introduction of laparoscopic cholecystectomy. Dig Dis Sci 2007; 52(5):1313-25.

5. Lima EC, Queiroz FL, Ladeira FN, Ferreira BM, Bueno JGP Magalhães EA. Análise dos fatores implicados na conversão da colecistectomia laparoscópica. Rev Col Bras Cir 2007; 34(5):321-5.

6. Polychronidis A, Botaitis S, Tsaroucha A, Tripsianis G, Bounovas A, Pitiakoudis $\mathrm{M}$, et al. Laparoscopic cholecystectomy in elderly patients. J Gastrointest Liver Dis 2008; 17(3):309-13.

7. Annamaneni RK, Moraitis D, Cayten CG. Laparoscopic cholecystectomy in the elderly. JSLS 2005; 9(4):408-10.

8. Kim HO, Yun JW, Shin JH, Hwang SI, Cho YK, Son BH, et al Outcome of laparoscopic cholecystectomy is not influenced by chronological age in the elderly. World J Gastroenterol 2009; 15(6):722-6.

9. Cheng $S P$, Chang $Y C$, Liu $C L$, Yang $T L$, Jeng $K S$, Lee JJ, et al. Factors associated with prolonged stay after laparoscopic cholecystectomy in elderly patients. Surg Endosc 2008; 22(5):12839 .

10. Malik AM, Laghari AA, Talpur KA, Memon A, Pathan R, Memon JM. Laparoscopic cholecystectomy in the elderly patients. An experience at Liaquat University Hospital Jamshoro. J Ayub Med Coll Abbottabad 2007; 19(4):45-8.

11. Lyass S, Perry Y, Venturero M, Muggia-Sullam M, Eid A, Durst A, Reissman P. Laparoscopic cholecystectomy: what does affect the outcome ? A retrospective multifactorial regression analysis. Surg Endosc 2000; 14(7):661-5.

12. Ibanez AL, Escalona PA, Devaud JN, Monteiro MP, Ramirez WE, Pimentel MF, et al. Laparoscopic cholecystectomy: 10 years at the Hospital Clínico Pontificia Universidad Católica de Chile. Rev Chil Cir 2007; 59(1):10-5

13. Amaral PCG, Ázaro Filho EM, Fortes MF, Ettinger Jr E, Cangussu HC, Fahel E. Taxas de complicações e tempo de permanência hospitalar foram maiores em pacientes idosos submetidos à videolaparocolecistectomia. Resultados após colecistectomia videolaparoscópica em pacientes idosos. Rev bras videocir 2006; 4(2):48-53

14. Johansson M, Thune A, Nelvin L, Lundell L. Randomized clinical trial of day-care versus overnight-stay laparoscopic cholecystectomy. $\mathrm{Br} J$ Surg 2006; 93(1):40-5.
15. Golden WE, Cleves MA, Johnston JC. Laparoscopic cholecystectomy in the geriatric population. J Am Geriatr Soc 1996; 44(11):1380-3.

16. Coelho JC, Bonilha R, Pitaki SA, Cordeiro RM, Salvalaggio PR, Bonin EA, et al. Prevalence of gallstones in a Brazilian population. Int Surg 1999; 84(1):25-8

17. Milcent M, Santos EG, Bravo Neto GP. Lesão iatrogênica da via biliar principal em colecistectomia videolaparoscópica. Rev Col Bras Cir 2005; 32(6):332-6

18. Mayol J, Martinez-Sarmiento J, Tamayo FJ, Fernandez-Represa JA. Complications of laparoscopic cholecystectomy in the ageing patient. Age Ageing 1997; 26(2):77-81.

19. Pavlidis TE, Marakis GN, Symeonidis N, Psarras K, Ballas K, Rafailidis $\mathrm{S}$, et al. Considerations concerning laparoscopic cholecystectomy in the extremely elderly. J Laparoendosc Adv Surg Tech A 2008, 18(1):56-60

20. Montalva NS, Flisfisch FH, Lena PL, Cerda SR, Hernandez FF, Matus FC, et al. Resultados de la colecistectomía videolaparoscópica en el adulto mayor. Rev chil cir 2007; 59(6):425-9.

21. Brunt LM, Quasebarth MA, Dunnegan DL, Soper NJ. Outcomes analysis of laparoscopic cholecystectomy in the extremely elderly. Surg Endosc 2001; 15(7):700-5

22. Chang WT, Yu FJ, Hsieh MY, Huang MC, Lee KT, Chen JS, et al Laparoscopic cholecystectomy in aged patients. Hepatogastroenterology 2009; 56(93):950-5.

23. Osman $Y$, Ebru M, Umit T, Volkan O, Melih K, Belma K, et al Laparoscopic cholecystectomy in elderly patients. Bratisl Lek Lisly 2008; 109(7):313-6.

24. Karayiannakis AJ, Makri GG, Mantzioka A, Karousos D, Karatzas G. Systemic stress response after laparoscopic or open cholecystectomy: a randomized trial. Br J Surg 1997; 84(4):46771 .

25. Hangui RMG, Rêgo REC, Demarchi VCA, Tomasich FDS, Pacheco Júnior AM. Complicações pós-operatórias de colecistectomias: análise comparativa em relação ao sexo. Rev Col Bras Cir 2004 31(1):57-63.

26. Casaroli AA, Bevilacqua RG, Rasslan S. Análise multivariada dos fatores de risco no tratamento cirúrgico da colecistite aguda no idoso. Rev Col Bras Cir 1996; 23(1):1-7.

Received on 19/04/2010

Accepted for publication 17/06/2010

Conflict of interest: none

Source of funding: Institute of solidarity of the Holy Spirit

How to cite this article:

Loureiro ER, Klein SC, Pavan CC, Almeida LDLF, Silva FHP, Paulo DNS. Laparoscopic cholecystectomy in 960 elderly patients. Rev Col Bras Cir. [periódico na Internet] 2011; 38(3). Disponível em URL: http:// www.scielo.br/rcbc

\section{Correspondence to:}

Edson Ricardo Bittencourt

E-mail: Er.loureiro@uol.com.br 